\title{
TEACHING ASSIMILATIONS TO IMPROVE LISTENING SKILLS FOR VIETNAMESE STUDENTS
}

\section{Du Thanh Tran}

\section{Article History}

Received: 18 September 2020

Accepted: 21 November 2020

Published: 30 December 2020

\section{Keywords}

Assimilation, connected speech sounds, listening skills

\author{
Thu Dau Mot University, Vietnam \\ Email:dutt@tdmu.edu.vn
}

\section{INTRODUCTION}

It is generally such a formidable challenge to improve English learners' listening competencies that virtually no students feel quite confident when taking a listening exams though they are fairly good at other skills (Austin, 1970). Listening is, in fact, a demanding process, not only because of the complexity of the process itself but also due to numerous other processes, such as recognizing phonological sound differences, guessing the ideas, comprehending grammatical structures, etc. (Luu Quy Khuong, 2000, p.42-43).

According to Celce-Murcia et al. (2002, p.22), the ability to process, segment and decode speech depends not only on learners' knowledge of lexicon but also on their being able to exploit knowledge of the sound system of the language. For most Vietnamese students, listening is difficult due to various reasons, among which is students' insufficient knowledge of the sound system of the language. As a result of the mother tongue's sound system interference, Vietnamese students can easily recognize words spoken in isolation; however, very few can recognize them in casual, fast and natural speech. Consequently, they often fail to have an accurate comprehension of what are naturally spoken by English native speakers. When students are unaware of accurate sound perception and recognition, listening comprehension is a real challenge to them.

Therefore, knowledge of assimilation as a feature of connected speech sounds, which the author is going to discuss below is "not only important in helping students to improve their production of spoken English but also essential in helping students to improve their listening comprehension" (Avery and Ehrich, 1995, p.81). Regarding the practical applications, this study aims at building up students' awareness and provide useful practice of the problematic sounds they have to deal with in listening to colloquial, casual and connected speech, thus outlining ways to improve listening skills for students in Vietnamese contexts.

\section{LITERATURE REVIEW}

Knowing a language means one can speak and be understood by others who use that language. In other words, "you have the capacity to produce sounds that signify certain meanings and to understand or interpret the sounds produced by others" (Fromkin et al., 1988, p.3). One of the effective ways to develop these capacities for students is to provide them with knowledge and ability of recognition of the sound systems of the language. This kind of knowledge includes "more than knowing the inventory of sounds", but "knowing which sounds may start a word, end a word, and follow each other when they occur in a sequence of speech" (Fromkin et al., 1988, p.4).

Together with speaking, listening has long been considered a basic and important skill in acquiring as well as in using a language. It is considered as a medium through which children, young people and adults gain a large portion of their education, their information, their understanding of the world and human affairs, their ideals, their sense of values and appreciations, etc. 
In English, the production of sounds is usually influenced by the context in which they appear in a sequence of words. As Roach (2000, p.138) states, a specific sound is, in most cases, influenced by its neighboring sounds. In a certain context, certain sounds are unreleased. Sometimes, it takes the characteristics of the surrounding sounds. Sometimes, it turns into another sound. Sometimes, the sound of one word chunks into the first sound of the following words. In most cases, consonants and vowels within words are affected by the position in which they occur. These processes of producing sounds may happen within words or at the word boundaries and the sounds produced in one of these manners are considered as connected speech sounds. While the use of connected speech sounds is not considered as "lazy" or "floppy", the main function of these processes is to ease the working of the articulatory system. It is a common feature of fluent, natural speech (Celce-Murcia et al., 2002, p.259).

According to Bert (1983), the sounds of a language must be learnt in order to understand speech. This is obvious as it is not the sound system that causes the most comprehensive problems, but the way they vary in normal speech. In rapid, natural speech, adjacent sounds influence each other. Ur (1996, p.17) states: "A learner listening to spoken discourse in a foreign language will probably not understand a word he has not learnt yet. Nevertheless, he will also fail to recognize many words he has learnt but is not yet sufficiently familiar with to identify when they occur within the swift stream of speech".

In order to perceive, interpret and evaluate spoken English, it is necessary to have internalized knowledge of English stress and intonation, English vowels and consonants when they occur in connected speech. As listening proficiency plays a vital role in learners' overall communicative competence which requires that learners be able to discriminate as well as produce functionally significant distinctions in their spoken English (Celce-Murcia et al., 2003, p.244), knowledge of connected speech sounds is of great help to build up students' language competence in general and their listening competence in particular.

In speech, the sounds produced are subjected, in general, to two types of influence: the reciprocal influence of neighboring sounds and the influence of sounds by larger speech units and their elements, first of all, by stress. The first type includes combinative changes and the second type includes positional changes (Jones and Daniel, 1996). As a result of mutual interaction of sounds in connected speech, there are a number of phonetic processes such as assimilations, elisions, accommodations, and others.

Assimilation is a process in which a given sound takes some of the characteristics of a neighboring sound (Celce Murcia, 2002; Richards et al., 1992). In English, a certain sound in a string of phonemes would not remain the same as when it is spoken in isolation (Finegan, 1994). As a feature of spoken language, assimilation is more likely to be found in rapid, casual speech and less likely to be found in slow, careful speech (Roach, 2000, p.139). It only occurs frequently, both within words and between words. In speaking, assimilation production can be helpful for speakers to provide natural, smooth and fluent connected speech. In listening, assimilation awareness can help listeners comprehend and interpret the speech.

In linguistics, there are many ways to classify assimilation rules. Taking the dimension of sound changes into consideration, assimilations in English can be divided into three kinds: (i) progressive assimilations; (ii) regressive assimilations and (iii) coalescent assimilations (Celce-Murcia, 2002, p.159-162):

In progressive assimilations: The conditioning sound precedes and affects the following sound. When the final consonant is a plosive or a nasal such as $/ \mathrm{t} / \mathrm{d} / \mathrm{d}$, or $/ \mathrm{n} /$ followed by a fricative like /s/, that initial consonant will be changed into a plosive or a nasal, just like the final consonant. For example:

+ "get them" (with /t/ followed by /ð/) should be pronounced as /get təm/ rather than /get ðəm/.

+ "read these" (with/d/ followed by /ð/) should be pronounced as /ri:d di:z/ rather than /ri:d ði:z/.

Progressive assimilations can also occur in some reductions. The case of "had to" can be taken as a typical example for this. This phrase is originally pronounced as /hæd tu:/ but as "to" is tended to be pronounced as /tə/ in weak forms, the whole phrase is reduced to /hæd tə/. Then /d/ in "had" conditions /t/ in /tə/ and makes /tə/ change into /də/. As a result, "had to" is pronounced as /hædə/ in natural speech.

In regressive assimilations: The assimilated sound precedes and is affected by the conditioning sound. This kind of assimilations can be categorized in three ways: (i) in terms of place of articulation; (ii) in terms of manner of articulation and (iii) in terms of voicing.

- In terms of place of articulation: When the final consonant is an alveolar or a bilabial such as $/ \mathrm{t} /, / \mathrm{d} /$, or $/ \mathrm{n} /$ followed by a bilabial such as $/ \mathrm{p}, / \mathrm{b} /, / \mathrm{m} /$, that final consonant will be changed into a bilabial such as $/ \mathrm{p} /, / \mathrm{b} /, / \mathrm{m} /$ correspondingly, as in the following examples: 
+ "that person" should be pronounced as /ðæp p3rsən/ rather than /ðæt p3rsən/.

+ "red pain" should be pronounced as /reb peint/ rather than /red peint/.

+ "chicken breast" should be pronounced as /'tfikim brest/ rather than /'t tfikin brest/.

When the final consonant is an alveolar such as $/ \mathrm{t} /, / \mathrm{d} /$, or $/ \mathrm{n} /$ followed by a velar such as $/ \mathrm{k} /, / \mathrm{g} /$, that final consonant will be changed into a velar such as $/ \mathrm{k} /, / \mathrm{g} /$ correspondingly, as in the following examples:

+ "white coat" should be pronounced as /wai:t kout/ rather than /wai:k kout/.

+ "bad girl" should be pronounced as /bæg g3:1/ rather than /bæd g3:1/.

+ "main gate" should be pronounced as /mein geit/ rather than /mein geit/.

When the final consonant is an alveolar such as $/ \mathrm{s} /$, /z/ followed by a palatal-alveolar or a palatal such as $/ \mathrm{J} /, / \mathrm{j} /$, that final consonant will be changed into a palatal-alveolar or a palatal such as $/ \mathrm{g} /$ or $/ \mathrm{j} /$, as in the following examples:

+ "nice shoes" should be pronounced as /naif Ju:/ rather than /nais Ju:/.

+ "wise youngster" should be pronounced as /waiz ' $\mathrm{j} \Lambda \eta \mathrm{st} /$ / rather than /waiz ' $\mathrm{j} \Lambda \eta \mathrm{st} / \mathrm{s}$.

- In terms of manner of articulation: When the final consonant is a plosive such as $/ \mathrm{t} /, / \mathrm{d} /$ followed by a fricative or a nasal such as $/ \mathrm{s} /, / \mathrm{z} /, / \mathrm{n} /$ or $/ \mathrm{z} /$, that final consonant will be changed into a fricative or a nasal such as $/ \mathrm{s} /, / \mathrm{z} /$, or $/ \mathrm{n} /$ respectively, as in the following examples:

+ "that side" should be pronounced as /ðæs said/ rather than /ðæt said/.

+ "good singer" should be pronounced as /gus "sinə/ rather than /gud "sinə/.

- In terms of voicing: When a final consonant is a lenis such as $/ \mathrm{p}, / \mathrm{t} /$, or $/ \mathrm{g} /$ followed by a fortis such as $/ \mathrm{p} /, \mathrm{t} / \mathrm{t}$, or $/ \mathrm{k} /$, that final consonant will be changed into a fortis such as $/ \mathrm{p} /, / \mathrm{t} / / / \mathrm{k} /$, as in the following examples:

+ "rob Peter" should be pronounced as /rop "pi:tə/ rather than /rob "pi:tə/.

+ "bad tongue" should be pronounced as /bæt $t \wedge \eta /$ rather than /bæd $t \wedge \eta /$.

+ "big car" should be pronounced as /bik ka:/ rather than /big ka:/.

In coalescent assimilations: The first and the second sound in a sequence come together and naturally condition the creation of a third sound with features from both the original sounds. This process occurs most frequently in English when the final alveolar consonant such as /s/, /z/ and /t/, /d/ or final alveolar consonant sequences such as $/ \mathrm{t} / / / \mathrm{d} z /$ are followed by the initial palatal $/ \mathrm{j} /$. Then they become palatalized fricatives and affricatives respectively, as in the following examples:

+ He's coming this year. $(/ \mathrm{s} /+/ \mathrm{j} /=/ \mathrm{g} /)$.

+ Does your mother know? $(/ \mathrm{z} /+/ \mathrm{j} /=/ \mathrm{z} /)$;

+ Is that your $\operatorname{dog} ?(/ \mathrm{t} /+/ \mathrm{j} /=/ \mathrm{t} / \mathrm{f})$;

+ He hates your hairdo. $(/ \mathrm{ts} /+/ \mathrm{j} /=/ \mathrm{d} 3 /)$;

+ Would you mind moving? $(/ \mathrm{d} /+/ \mathrm{j} /=/ \mathrm{d} 3 /)$;

+ He needs your help. $(/ \mathrm{d} z /+/ \mathrm{j} /=/ \mathrm{d} 3 /)$.

In the scope of the study, the author only mentions and discusses in details assimilation rules that students often encounter in their listening comprehension practices.

\section{RESEARCH METHODS AND RESULTS}

\subsection{Research methods}

Together with document analyses, quantitative and qualitative research designs are also used. Conducted in a limited amount of time, the main purposes of the study are (i) to evaluate the effectiveness of teaching assimilation rules in improving students' listening comprehension abilities; and (ii) to find out the optimal ways to raise students' awareness, help them practice and recognise these sounds in listening comprehension texts. Accordingly, the study is specifically designed to find answers to the following questions: (i') How effective is teaching assimilation rules in improving students' listening comprehension abilities? (ii') How can teachers raise students' awareness and help them practice these sounds effectively? The data collected come from document reviews, actual teaching practice observations and discussions.

Regarding the objectives of the study, the experiment teaching was conducted at Thu Dau Mot University. The research participants include two groups of students taking the course on listening comprehension skills of Intermediate Level, in which one group were provided/ equipped with basic assimilation rules immediately prior to the course (Group A=50 students) and the other weren't (Group B=50 students). The input level of these two groups was supposed to be the same. Apart from 15 classroom periods, those from Group A were also provided with materials related to assimilation rules so that they can study and practice these sound aspects on their own. 
At the end of the experimental teaching, the final scores of the course were analyzed and compared using basic excel software to evaluate the effectiveness of the strategy under discussion. These scores were based on two listening comprehension tests (one test implemented during and the other one at the end of the course). Together with these scores, students' behaviors and satisfaction in the process of experimental teaching were also noted.

\subsection{Research results}

In order to evaluate the benefits of teaching assimilation rules in developing listening comprehension skills for students, the final scores of the two groups (the average of the tests implemented during and at the end of the course) were then analyzed and compared by the author. The principal goal of these tests was to evaluate students' abilities and performance in listening comprehension activities. These final results are generally presented in the following table:

Table. Final scores of the course

\begin{tabular}{ccccccc}
\hline \multirow{2}{*}{ Groups } & \multicolumn{5}{c}{ Final scores of the course } \\
\cline { 2 - 7 } & $<3$ & $<5$ & $5-6$ & $6-7$ & $7-8$ & $8-9$ \\
\hline Group A $(\mathrm{N}=50)$ & 0 & $1(2 \%)$ & $8(16 \%)$ & $15(30 \%)$ & $17(34 \%)$ & $9(18 \%)$ \\
\hline Group B $(\mathrm{N}=50)$ & $2(4 \%)$ & $5(10 \%)$ & $21(42 \%)$ & $13(26 \%)$ & $7(14 \%)$ & $2(4 \%)$ \\
\hline
\end{tabular}

As it is shown from the above table, students from Group A achieved better results at the end of the course. From the observation and investigation during the course, it is clear that the focused group really showed their interest and motivation in studying assimilation rules as they had realized the use of these rules in their language skill development. Some even asked their lecturer to give them more materials related to the rules so that they can study further on their own. The activities and tasks used to present these rules are considered to be appropriate and satisfactory for these students. Students also showed their confidence in listening activities during the course.

With a careful and thorough observation of English language teaching and learning in Vietnam, and from the experimental teaching, it is revealed through the study that the teaching of assimilation rules, as proposed by the researcher, can raise students' awareness and help them realize problematic sounds in casual colloquial connected speech. Given these contributions, the teaching of these rules, at first sight, has proved to be useful and effective in developing listening comprehension skills for Vietnamese students. It is, therefore, recommended to teach these fluency devices to enhance listening comprehension abilities for language learners in Vietnamese contexts.

\subsection{Assimilation teaching implications}

Pronunciation is one of the most influential factors in speaking and listening comprehension practices (Gilbert, 1996). It is, therefore, necessary for students to master pronunciation of the language in order to communicate effectively in that language. In English, there are a number of phenomena that are exploited by the native speakers to make their connected speech more fluent and speedy. Unfortunately, it is not easy for most Vietnamese learners of English to successfully discriminate functionally distinct sounds, to segment streams of speech into words or groups of words when they appear in colloquial connected speech. It is, therefore, suggested that assimilation rules should be introduced in Vietnamese contexts to help language learners improve their listening comprehension abilities. Based on pronunciation teaching materials and the author's teaching experience, the following phases should be taken into consideration to raise students' awareness and help them master these sound aspects:

- Introduction stage: It is a good idea to begin instructions of connected speech sounds by raising students' awareness of the concept of assimilation and its rules. They have to be convinced that it is "correct" to use connected speech sounds as these sounds are very often noticed in spoken language. As students realize the importance of connected speech sounds in speaking as well as in listening comprehension practices, they will be definitely motivated to learn them. Teachers first can have students listen to some sentences which contain related connected speech sounds, pronouncing these sounds in different manners (varying from slow speech to fast speech) and then comparing the sounds produced in different ways. Once students realize the difference, the teacher will then introduce the concept of assimilation and its rules.

- Presentation and controlled practice stage: After students have basic understanding of the concept and the sounds, it is time for the teacher to organize activities to familiarize students with accurate pronunciation and recognition of these sounds in spoken language (Avery, P and Ehrich, 1995; Kelly, 2000; Kenworthy, 1992; Sesnan, 2001). The following activities are meaningful practices for presenting and practicing these sounds/sound sequences:

+ Repetition: Teachers write one or two sentences with assimilations on the board (For example, 'Would you like to have dinner with me tonight?'), saying it aloud as in the awareness raising activity mentioned above, focusing students on the pronunciation of "Would you" in the whole sequence of speech, stating clearly to students that in 
fast, normal speech, these two words are pronounced as /wuddz/. Teachers then should have students read the model sentence out loud, and if necessary, teachers read first and students repeat until they gain the accurate pronunciation of the target sound sequence.

+ Substitution drill: After repetition stage, substitution drilling can help reinforce the accurate pronunciation of the targeted assimilation. This drilling should be done first in chorus and then individually. Choral drillings can help build up students' confidence and give them a good chance to practice without anxiety about their performance. After chorus drillings, the teacher will then call on individual students to speak the sentences. Based on students' performance, the teacher can determine how well they pronounce the sequences with assimilations.

+ Other activities: Together with repetition and substitution drillings, other kinds of activities are also helpful. An instance is recording students' voices. In this activity, students are required to act out the dialogue or read aloud the passage which contains assimilations. Once recording practice is completed, the teacher and students begin comparing their recordings with those made by English native speakers. Together with recording students' voices, having students predict or find sequences of words (both in written texts or in recorded materials) which contain assimilations would be also helpful.

- Further practice stage: Similar to teaching other phonological features of the language, controlled practice is still insufficient in teaching assimilations in Vietnamese contexts. It is, therefore, necessary for the teacher to involve students in further practice with communicative activities such as playing games, practicing dialogues, role-play, etc. As Avery and Ehrich (1995, p.65) states, pronunciation can be both interesting and fun for students when taught communicatively. By using these communicative activities, students will be more exposed to connected speech sounds in general and to assimilations in particular in the process of sound production in speaking and sound perception in listening comprehension as well.

\section{DISCUSSION AND CONCLUSION}

Teaching practice shows that it is a formidable challenge for Vietnamese students to recognize assimilated sounds when they appear in speech. This results in their failure to perform well in listening comprehension or perceive accurately what is naturally spoken. These students may also fail to make themselves understood during their oral communication. Therefore, acquiring this aspects of connected speech is crucial for speaking as well as listening comprehension. Mastering connected speech sounds in general and assimilations in particular can make a great contribution to good listening comprehension skills. To help students develop the ability of listening comprehension, teachers should raise students' awareness of these sounds, giving them sufficient practice both in producing and recognizing these sounds in speech. With appropriate strategies and techniques presented in the study, it is hoped that teachers can raise students' awareness and give them opportunities to practice these sound aspects in their language classes effectively.

\section{REFERENCES}

Austin, S. (1970). Speaking and Listening: A Contemporary Approach. America: Harcourt, Prace and Word, Inc. Avery, P. \& Ehrich, S. (1995). Teaching American English Pronunciation (3 ${ }^{\text {rd }}$ edition). Oxford: OUP.

Bert, G. J. B. (1983). Pronunciation and Listening Comprehension. Cambridge: CUP.

Celce-Murcia, et al. (2002). Teaching Pronunciation: A Reference for Teachers of English. Cambridge: CUP.

Finegan, E. (1994). Language - Its Structure and Use ( $2^{\text {nd }}$ Edition). Harcourt Brace \& Company.

Fromkin, et al. (1988). Introduction to Language. Australia: Harcourt Brace Jovanovich Limited.

Gilbert, B. J. (1996). Clear Speech. Cambridge: CUP.

Jones \& Daniel (1996). The Pronunciation of English. Cambridge: CUP.

Kelly, G. (2000). How to Teach Pronunciation. Longman: Pearson Education.

Kenworthy, J. (1992). Teaching English Pronunciation. Longman.

Khuong, Luu Quy (2000). A Practical Course for Teaching English as a Foreign Language. Da Nang University Press.

Richards, J., Platt, J. \& Platt, H. (1992). Longman Dictionary of Language Teaching and Applied Linguistics. Longman Group UK Limited.

Rixon, S. (1981). The Design of Materials to Foster Particular Listening Strategies in the Teaching of Listening Comprehension. London: The British Council.

Roach, P. (2000). English Phonetics and Phonology ( $3^{\text {rd }}$ edition). Cambridge: CUP.

Sesnan, B. (2001). How to Teach English. Oxford: OUP.

Ur, P. (1996). Teaching Listening Comprehension. Cambridge: CUP. 